\title{
USING SINGLE VALUED NEUTROSOPHIC SET TO SELECT TOURISM DEVELOPMENT STRATEGIES IN EASTERN SERBIA
}

Snežana Urošević ${ }^{1}$, Dragiša Stanujkić ${ }^{2}$, Darjan Karabašević ${ }^{3}$, Pavle Brzaković ${ }^{4}$

*Corresponding authorE-mail: surosevic@tfbor.ac.rs

A R T I C L E I N F O
Original Article
Received: 23 January 2018
Accepted: 17 May 2018
doi:10.5937/ekoPolj1802555U
UDC 338.486.41:65.011.12(497.11-11)

Keywords:

Eastern Serbia, tourism, natural resources, social resources, human resources, neutrosophic sets

JEL: D81, Z30, Z32

\begin{abstract}
A B S T R A C T
Natural beauties of Eastern Serbia combined with the culture, traditions, food specialties and music, can become a recognizable tourism brand, which could improve the image of this part of Serbia, and that is the reason why Eastern Serbia has been recently discovering its potential for tourism development. The aim of this paper is to analyze the current and potential elements for tourism development of Eastern Serbia's products. Based on the relevant literature and factual situation on the field, the goal is to rank strategies for tourism development on the territory of Eastern Serbia in order to enable better positioning of tourism in Eastern Serbia on the Serbian tourist map. In order to rank tourism development strategies we have used neutrosophic sets. The justification and usability of the proposed approach for the selection of tourism development strategy is demonstrated in the implemented numerical example.
\end{abstract}

(C) 2018 EA. All rights reserved.

\section{Introduction}

Modern tourism in the world, but also in our country, is manifested as a very significant spatial phenomenon. Tourism and geographic space with their attributes are inseparable concepts in the realization of tourism trends. Therefore, we have to consider the characteristics of certain areas in which tourism has developed and created well-known

1 Snežana Urošević Ph.D., Professor, Technical faculty in Bor, University of Belgrade, Vojske Jugoslavije 12, 19210, Bor, phone: +381607150305, e-mail: surosevic@tfbor.ac.rs, ORCID ID http://orcid.org/0000-0002-6647-0449

2 Dragiša Stanujkić Ph.D., Associate Professor, Technical faculty in Bor, University of Belgrade, Vojske Jugoslavije 12, 19210, Bor, phone: +381603545565, e-mail: dstanujkic@ tfbor.ac.rs, ORCID ID https://orcid.org/0000-0002-6846-3074

3 Darjan Karabašević Ph.D., Assistant Professor, Faculty of Applied Management, Economics and Finance, University Business Academy in Novi Sad, Jevrejska 24, 11000, Belgrade, phone: +381603383333, e-mail: darjan.karabasevic@mef.edu.rs, ORCID ID https://orcid. org/0000-0001-5308-2503

4 Pavle Brzaković M.Sc., Assistant, Faculty of Applied Management, Economics and Finance, University Business Academy in Novi Sad, Jevrejska 24, 11000, Belgrade, phone: +381643290255, e-mail: pavle.brzakovic@mef.edu.rs, ORCID ID https://orcid.org/00000001-5184-9627 
tourist destinations. The tourist destination consists of its attributes and the degree of their use, so depending on that, we can say whether it is a potential or already developed tourist destination.

The main resources of tourism development are natural resources, which we can consider a gift from nature, and which are used in the reproduction process of setting new useful values (Nikolić et al., 2013). Proper understanding of this process enables the dynamics of tourism development, as well as the identification of the main factors influencing changes in tourism development (Streimikiene and Bilan, 2015). The development and impact of tourism have significantly changed not only the original image of nature, but they also have formed new kinds of businesses. This means that for good economic and tourist valorization of space we need a good geographical basis, justified and applicative. Today, it is very important to create a strategy of a tourist destination and its appearance in the tourism market, while the correct strategy of performance is possible to choose only after considering the internal and external factors in the environment.

The territory of Eastern Serbia has natural and anthropogenic tourist potentials. The most important natural conditions and resources for the development of tourism are: relief, climate, water resources, flora and fauna properties, as well as other specificities of the natural environment. It has been proven that rich natural resources can provide a good comparative advantage in the tourism market; however, this necessarily requires investment in marketing strategy (Riznić et al., 2011). In this area there are also numerous nature reserves, monasteries, archaeological sites and, generally speaking, there is very important anthropogenic and natural heritage, important for both, this area and for the whole state. For the analysis of natural conditions that influence the development of tourism in the area of Eastern Serbia, we have used only those natural elements that can be placed relatively quickly in the tourist offer, although this area is extremely attractive for the development of various tourism forms and products (Cvijanović, 2014).

Architecture in urban and rural areas is very characteristic, and numerous rural ambient units are true representatives of the rural lifestyle of people in this area. Multiethnicity, represented by a wide spectrum of different content related to the customs and the life of locals in rural areas, is a chance that should be insisted on in the cultural offer of this area. A great cultural value also lies in the products of old crafts and handicrafts that are excellent representatives of the rich cultural heritage. The natural beauties of Djerdap, mountain Stara Planina, mountains Homoljske planine and many other attractive destinations, combined with culture, tradition, gastronomic specialties and music of Eastern Serbia, can become a recognizable tourist brand, which will significantly contribute to the income and improve the image of this region and the Republic of Serbia.

\section{Strategies of tourist destinations positioning}

The development of tourism and the increased participation of tourists in this kind of activities on the global level also enlarged the number of tourist destinations, which created a high level of competition in the world market. Tourist destinations have to 
create promotional activities and a special image for the selected market. It all makes necessary to carefully consider the approach for the tourist destination positioning. The rising trend of tourist demand for new challenges imposes the need for better positioning of existing destinations and/or creating new ones in order to achieve better economic profit. The space, which initially met the basic needs for rest and recreation, today must possess exceptional specifics in order to be interesting among diverse tourist demand. A specific position on the tourist map of the region can be taken by choosing the appropriate strategies, as well as the positioning instruments. Positioning also represents the development of the image of tourist destinations that are in direct contradiction with the competition.

The positioning of tourism products has the influence on the awareness of potential consumers (service users) in order to develop a positive image of a specific product (tourist destination), where potential consumers become loyal consumers (service users). Positioning is a way of communicating a destination to consumers with the desire to influence their decision making process related to travels. This is a complex process that requires careful analysis of all attributes of the destination and characteristics of the target market (Štetić, 2003). This influence is seen as a cause-effect relation between destination and consumer, and the ultimate outcome is the consumers' (tourists') choice of the right destination. Therefore, the choice of a positioning strategy that would create a positive image and the desire of tourists to stay at that particular destination is a basic precondition for the proper performing strategy on a particular market. For successful positioning, it is necessary to understand consumer behavior (service user). When managing the tourist destination, the most important is to achieve the right balance between stakeholders, while the local community has the most important role - the community will feel most of the effects of tourism development (Galanta et al., 2016; Jawabreh, 2014).

Strategic changes of tourism in Serbia, according to the market changes and the strategic goals of the development of tourist destinations, require the identification of priority types of tourism (Čerović and Petović, 2006). Compared to the world's tourist trends, Serbia is a relatively new destination that seeks to take a favorable place in the tourism market through the development strategy.

\section{Prospects for the development of tourism market based on natural and social resources}

In Eastern Serbia there are great opportunities for tourism development. Eastern Serbia has real resources, which the Republic of Serbia has to recognize and put into function of its long-term tourism development. A large number of natural resources, as well as anthropogenic resources, are very important for this region. In addition, this area implies a dose of mysticism, mystery, special philosophy and beliefs that interpret life; in this part of Serbia reality and legends exist together. 
As promising forms of tourism, but unfortunately not fully developed and exploited in Eastern Serbia, we can distinguish the following:

- Rural tourism - This area provides a wide range of different possibilities, whether it's tourism that would rely on tourists' staying in village farms or other kind of tourism related to rural areas. Bearing in mind the tendencies in the tourism market to move beyond the concept of mass tourism, interest in rural tourism has recently been growing. Serbia has so far failed to develop rural tourism more extensively (Maksimović et al., 2016b). Thanks to the natural, ecological and ambient characteristics, different rural areas are very interesting and promising for the development of rural tourism. Adequately built holiday homes in a preserved natural environment, characterized by peace and quiet, are real "oases" for people from highly urbanized, industrial centers. The main characteristic of modern tourism is the incorporation of an efficient ecological component into the overall tourism product and its promotion, treating it as a very important element for achieving a competitive position in attracting new tourist users (Urošević et al., 2015).

- Ecotourism - Ecotourism is a new model of tourism related to developing awareness of the correlation between tourism and environment. Today, the importance of ecotourism is growing, not only as a sector with great potential for economic development - especially in poorly developed areas - but also as a powerful tool for conserving the natural environment, if it is properly planned, developed and managed. Ecotourism is also a reliable tool for improving the local economy, especially in underdeveloped areas, such as the area of Eastern Serbia. The conducted studies (Arsić et al., 2017) show that for the sustainability of ecotourism of the National Park "Djerdap" the most important is the industry that could contribute even more to the sustainability and its further development.

- Hunting tourism - It would primarily involve organized structure for hunting tourism, and then appropriate investments that would bring real effects. Certain investments outside the territory of the National Park "Djerdap" are also needed in order to build hunting grounds with adequate infrastructure that would help developing this type of tourism.

- Fishing tourism - The entire area around the Danube River Basin provides excellent conditions for the development of fishing tourism. In that sense, it would be necessary to make certain investments in places where the fish would be fed ("feeding sites"), spawn and caught.

- Food tourism - It would be based on the rich cuisine tradition of Eastern Serbia and organically produced food, which represent an important part of the demand on the tourist market. Numerous gastronomic specialties typical for this area provide ideal opportunities for the development of this type of tourism. 
- Photo safari - The area of the National Park "Djerdap" provides ideal conditions for this type of tourism, which is nowadays very popular in the Western European countries, as well as in the USA and Japan.

- Bike tourism - It represents the development of the adequate cycling trails and the infrastructure that would keep cyclist on the journey through this area. We have to emphasize that there is a significant demand from Western Europe for the routes in this part of the Balkans.

- Excursions - They would include visits to archaeological sites: Lepenski vir, Golubački grad, remains of Trajan's bridge, Djerdap hydroelectric power plant and Felix Romuliana archaeological site.

- Events - A large number of events that take place in the cities in this area can attract, and they are already attracting, a large number of tourists. Zaječar is widely known for the musical rock manifestation "Gitarijada", which has been organized for half a century. There are also "Days of Zoran Radmilović", "Days of Mokranjac", "Days of Hajduk Veljko", Balkan festival of traditional culture of Vlachs, as well as many other events that take place in this region of Serbia.

- Manifestation tourism - It is based on agro-food products. Some of the events that take place in Eastern Serbia provide a good basis for building the image of this region as a tourist destination. In that sense, it is necessary to insist on a certain number of native products, originated from these parts. Mainly, we have to insist on organically produced agricultural products.

- Mining tourism - Abandoned mining sites have been raising interest as tourist destinations since more attention has been paid to the development of mining tourism today, which is an important component for the development of not only tourism, but also for the integral and sustainable development of the whole region. Revitalization and transformation of old mines into cultural and tourist centers, ecologically healthy environment or industrial and cultural heritage that tourists would like to visit and to stay in is important for both, the development of tourist destinations and the development of local communities. On the slopes of Stara Planina Mountain, east of the settlement Kalna, in the beech forest zone, there is the mine field "Janja". In the last century, in the late fifties, there was an active exploitation of uranium in three mines: "Mezdreja", "Gabrovnica" and "Srneći Do", which ceased to operate in 1966. This mining site has its own peculiarities; however, these mining objects are deteriorating, even though they can be transformed into ethno or ecological centers, ecologically healthy environments that European tourists would be delighted to visit and stay in, while the other part can be organized as an industrial cultural heritage, and these cultural and historical goods should be placed under the protection of the state (Maksimović et al., 2016a). It is worth mentioning the new tourist destination, the pioneer of the mining tourism, the copper mine in Bor, where has been built 
a large reception area with capacity of up to 60 people on the 11 th cave horizon, where tourists can descend to a depth of 700 meters, take photos and talk to the miners. The mine also includes a viewpoint on the oldest surface mine deep about 500 meters (Maksimović et al., 2016c).

In the following years, it is primarily necessary to create the image of East Serbia as a tourist destination. This is an assumption based on which we could carry out the positioning of areas in potential markets, which would draw the attention of potential segments of consumers. The creation of the image should be carried out alongside with the image of whole Serbia; unfortunately, Serbia is not currently present in the international tourist market in an adequate way. The reasons for this lie in:

- Political situation in the area of Western Balkans in the last twenty years.

- Insufficient investments in tourism as an economic activity.

- Lack of the adequate strategy for the tourism development etc.

Spiking in long terms, it is necessary to focus on the surrounding countries, mainly on Romania and Bulgaria. We should achieve an adequate level of cross-border cooperation with them, considering common resources (the area of the National Park "Djerdap" belongs to the Republic of Serbia, but also to the Republic of Romania with its peripheral parts and resource bases, as well as Stara Planina Mountain, which extends mostly on the territory of Bulgaria).

\section{Selection of tourism development strategy in Eastern Serbia}

For the development of tourism in Eastern Serbia there have been suggested four strategies:

- Strategy $A_{1}-$ Aggressive marketing, propaganda and market appearance of tourism.

- Strategy $A_{2}$ - Creation of the necessary infrastructure that will help the development of tourism.

- Strategy $A_{3}$ - Preserving local culinary tradition and the development of indigenous species in organic farming and cattle breeding.

- Strategy $A_{4}-$ Development of human resources in the field of tourism.

On the basis on the relevant literature and the factual situation on the field, we will carry out the ranking of the mentioned strategies in order to select the best among them. The goal is to establish better position of tourism of this region on the tourist map of Serbia.

Strategy $A_{1}$ - Aggressive marketing, propaganda and market appearance of Eastern Serbia tourism. This strategy aims to establish an efficient marketing system in order to break the destination into target markets and market niches, to constantly identify sources of new competitive advantages and to monitor the capacity of loyalty, i.e. recommendations for visiting the destination. The latest definition of marketing in tourism has become even more complex and complemented by the demand for a new concept of sustainable development, which, in addition to its orientation towards society, 
must be oriented towards nature and the environment. According to this, marketing must get a socially responsible development function, because it has to satisfy three basic tasks, i.e. three demands: to satisfy demand, to profit and to preserve nature. Marketing in tourism has two dimensions. The first dimension is based on market research, for the purpose of gathering information in order to meet market needs and to facilitate a harmonious development of the tourism market. The second dimension is that marketing should be humanized in order to understand the values and significance of many factors related to the natural environment (Vojnović et al., 2012).

Tourist propaganda is one of the instruments of tourist policy aimed to achieve certain goals, which means that the actions of tourist propaganda must be preconceived. Tourist propaganda should be viewed integrally with other instruments of tourism, such as business policy, price policy, tourism development policy and the like (Unković and Zečević, 2009), but it can also be an incentive to the public and private sectors aimed at increasing the number of visitors and rational use of energy and other resources (Petrić and Mandić, 2014). For this strategy, it is important to build an appropriate image in consumers' mind, which should represent the destination attractive in both ways, natural and cultural. It is necessary to invest in the promotion of this region and the creation of the image of this tourist destination that would become recognizable on the tourist market.

\section{Strategy $A_{2}$ - Creation of the necessary infrastructure that will help the development} of tourism. An important factor that affects the successful selection of the strategy lies in the necessity to develop an infrastructure that would consist of accommodation, sports facilities, new access roads, educational camps as well as places for excursions and active entertainment (Nurić et al., 2015). We cannot emphasize enough the significance of the road infrastructure development from the point of view of tourism development in the region. The quality of the transport and supply network must be at a satisfactory level in order to make an impact on the tourism development of a destination. The most significant impact on the extent of tourism business is hotel offer, accommodation and food facilities. Also, the development of a certain number of holiday-resort sites for nature lovers and the improvement of the offer of facilities that provide food and beverage can greatly help the development of tourism in Eastern Serbia.

\section{Strategy $A_{3}$ - Preserving local culinary tradition thorough the development of} indigenous species in organic farming and cattle breeding. What makes the area of Eastern Serbia truly recognizable is traditional cuisine. Local cuisine creates a unique feeling of hospitality and welcoming atmosphere. For livestock breeding development, e.g. on Stara Planina Mountain, we have adequate natural conditions, experience in livestock breeding gained through centuries, as well as the renown products from this area on the market. The ability to produce healthy food for the wider market in this ecologically clean environment is a comparative advantage, which prioritize the livestock breeding in this part of Serbia over other agricultural sectors. After obtaining the results of the pesticide impact on human health, organic production has been dispersed; it is an answer to all negative effects of the conventional production. Organic fruits, vegetables, meat, milk and other products have become highly demanded in the 
market. Organic production includes indigenous species, whose existence is related to the area in which they were created; they are also well adapted to the natural conditions of the area where they are being produced. The importance of indigenous species in organic production is multiple. Apart from being very adaptable to the conditions, the cultivation of these plant and animal species preserves the natural biodiversity of the ecosystem in which they are found. Among the autochthonous products, the most characteristic are dairy products: cheese from Stara Planina (Pirot), butter, urda, sheep cheese, white cheese - slice, vurda, sour milk. This region is famous for its dairy products and lamb production, as well as for mushrooms and fruit: apples, pears, blueberries, blackberries, which give opportunities for the development of culinary tourism.

Strategy $\boldsymbol{A}_{4}$ - Development of human resources in the field of tourism in Eastern

Serbia. The quality of tourist services depends to a large extent on the quality of performance, good will and education of human resources at all levels. This immediately encompasses the question: how is the importance of the human factor (as the carrier and executor of tourist activities in a certain area) being perceived? Tourism is a laborintensive activity, which means that a lot of human potential is needed in order to carry out this economic activity. Modern technical aids mainly contribute to the acceleration of individual work processes, changing the technology of work, but, as a rule, have a smaller impact on the reduction of the number of employees, especially in the catering industry. Tourism is an economic activity that largely depends on the human factor, because in tourism, people interact with consumers/tourists (Cvijanović and Vukovic, 2012).

\section{The Single Valued Neutrosophic Set}

The neutrosophic set (NS) is proposed by Smarandache (1998) in order to cope with problems that are associated with inconsistent and undetermined information. Further, Smarandache (1998) and Wang et al. (2010) proposed the single valued neutrosophic set (SVNS) suitable for solving many real-world decision-making problems. Until now, NS has been applied in numerous cases for solving a wide range of problems such as: Sustainable market valuation of buildings by the single-valued neutrosophic MAMVA method (Zavadskas et al., 2017), Garage location selection for residential house by WASPAS-SVNS method (Baušys and Juodagalvienè, 2017), restaurant selection (Stanujkic et al., 2016) and so on.

\section{Basic definitions and operations with the SVNS}

Definition 1. Let $X$ be the universe of discourse, with a generic element in $X$ denoted by $x$. Then, the Neutrosophic Set (NS) $A$ in $X$ is as follows (Smarandache, 1999):

$$
A=\left\{x<T_{A}(x) I_{A}(x) F_{A}(x)>\mid x \in X\right\},
$$

where $T_{A}(x), I_{A}(x)$ and $F_{A}(x)$ are the truth-membership function, the indeterminacymembership function and the falsity-membership function, respectively, $\left.T_{A}, I_{A}, F_{A}: X \rightarrow\right]^{-} 0,1^{+}\left[\right.$and $^{-} 0 \leq T_{A}(x)+I_{A}(x)+U_{A}(x) \leq 3^{+}$ 
Definition 2. Let $X$ be the universe of discourse. The Single Valued Neutrosophic Set (SVNS) A over $X$ is an object having the form (Smarandache, 1998; Wang et al., 2010):

$$
A=\left\{x<T_{A}(x) I_{A}(x) F_{A}(x)>\mid x \in X\right\},
$$

where $T_{A}(x), I_{A}(x)$ and $F_{A}(x)$ are the truth-membership function, the intermediacymembership function and the falsity-membership function, respectively, $T_{A}, I_{A}, F_{A}: X \rightarrow[0,1]$ and $0 \leq T_{A}(x)+I_{A}(x)+U_{A}(x) \leq 3$.

Definition 3. For an SVNS $A$ in $X$, the triple $<t_{A}, i_{A}, f_{A}>$ is called the single valued neutrosophic number (SVNN) Smarandache (1999).

Definition 4. SVNNS. Let $x_{1} \leqslant t_{1}, i_{1}, f_{1}>$ and $x_{2} \leqslant t_{2}, i_{2}, f_{2}>$ be two SVNNs and $\lambda>0$ ; then, the basic operations are defined as follows:

$$
\begin{aligned}
& x_{1}+x_{2} \leqslant t_{1}+t_{2}-t_{1} t_{2}, i_{1} i_{2}, f_{1} f_{2}>. \\
& x_{1} \cdot x_{2} \leqslant t_{1} t_{2}, i_{1}+i_{2}-i_{1} i_{2}, f_{1}+f_{2}-f_{1} f_{2}>. \\
& \lambda x_{1}<1-\left(1-t_{1}\right)^{\lambda}, i_{1}^{\lambda}, f_{1}^{\lambda}>. \\
& x_{1}^{\lambda}<t_{1}^{\lambda}, i_{1}^{\lambda}, 1-\left(1-f_{1}\right)^{\lambda}>.
\end{aligned}
$$

Definition 5. Let $x \leqslant t_{x}, i_{\mathrm{x}}, f_{x}>$ be a SVNN; then the cosine similarity measure $S_{(x)}$ between SVNN $x$ and the ideal alternative (point) $<1,0,0>$ can be defined as follows (Şahin, 2014; Ye, 2014):

$$
S_{(x)}=\frac{t}{\sqrt{t^{2}+i^{2}+f^{2}}} .
$$

Definition 6. Let $A_{j}<t_{j}, i_{\mathrm{j}}, f_{j}>$ be a collection of SVNSs and $W=\left(w_{1}, w_{2}, \ldots, w_{n}\right)^{T}$ be an associated weighting vector. Then the Single Valued Neutrosophic Weighted Average (SVNWA) operator of $A_{j}$ is as follows (Şahin, 2014):

$$
\begin{aligned}
& \operatorname{SVNWA}\left(A_{1}, A_{2}, \ldots, A_{n}\right)=\sum_{j=1}^{n} w_{j} A_{j} \\
& =\left(1-\prod_{j=1}^{n}\left(1-t_{j}\right)^{w_{j}}, \prod_{j=1}^{n}\left(i_{j}\right)^{w_{j}}, \prod_{j=1}^{n}\left(f_{j}\right)^{w_{j}}\right),
\end{aligned}
$$

where: $w_{j}$ is the element $j$ of the weighting vector, $w_{j} \in[0,1]$ and $\sum_{j=1}^{n} w_{j}=1$. 


\section{Numerical example}

With the goal to briefly demonstrate the proposed approach and show the efficiency and usability of the SVNS, a numerical example will be conducted in this section. Suppose that a 3 decision makers should evaluate the four development strategies denoted as $A_{1}$, $A_{2}$ and $A_{3 \text { and }} A_{4}$ discussed in previous section in relation to the five evaluation criteria with the same significance: $C_{1}-$ The implementation of the strategy feasibility; $C_{2}-$ The speed of implementation; $C_{3}$ - Compliance with the strategy of the development of tourism and local economic development; $C_{4}-$ An economic profit and $C_{5}-$ the satisfaction of service users.

At the beginning of the evaluation, decision makers evaluate alternatives. Ratings of the alternatives expressed in terms of the SVNS obtained on the basis of the three experts are given in Tables 1 to 3 .

Table 1. The ratings obtained based on the first expert

\begin{tabular}{|c|c|c|c|c|c|}
\hline & $C_{1}$ & $C_{2}$ & $C_{3}$ & $C_{4}$ & $C_{5}$ \\
\hline$w_{j}$ & 0.20 & 0.20 & 0.20 & 0.20 & 0.20 \\
\hline$A_{1}$ & $<0.7,0.2,0.2>$ & $<0.6,0.3,0.2>$ & $<0.59,0.15,0.4>$ & $<0.7,0.05,0.35>$ & $<0.7,0.05,0.3>$ \\
\hline$A_{2}$ & $<0.8,0.1,0.2>$ & $<0.65,0.15,0.3>$ & $<0.5,0.4,0.3>$ & $<0.55,0.05,0.4>$ & $<0.6,0.15,0.25>$ \\
\hline$A_{3}$ & $<0.65,0.1,0.3>$ & $<0.75,0.2,0.3>$ & $<0.55,0.3,0.4>$ & $<0.4,0.4,0.3>$ & $<0.45,0.3,0.35>$ \\
\hline$A_{4}$ & $<0.6,0.25,0.35>$ & $<0.65,0.05,0.35>$ & $<0.8,0.2,0.1>$ & $<0.9,0.15,0.05>$ & $<0.7,0.55,0.15>$ \\
\hline
\end{tabular}

Source: Authors' calculations

Table 2. The ratings obtained based on the second expert

\begin{tabular}{|c|c|c|c|c|c|}
\hline & $C_{1}$ & $C_{2}$ & $C_{3}$ & $C_{4}$ & $C_{5}$ \\
\hline$w_{j}$ & 0.20 & 0.20 & 0.20 & 0.20 & 0.20 \\
\hline$A_{1}$ & $<0.65,0.2,0.3>$ & $<0.55,0.15,0.2>$ & $<0.65,0.2,0.2>$ & $<0.55,0.1,0.3>$ & $<0.6,0.1,0.3>$ \\
\hline$A_{2}$ & $<0.85,0.2,0.1>$ & $<0.7,0.25,0.2>$ & $<0.6,0.35,0.15>$ & $<0.5,0.15,0.3>$ & $<0.65,0.05,0.35>$ \\
\hline$A_{3}$ & $<0.85,0.2,0.15>$ & $<0.8,0.2,0.2>$ & $<0.85,0.3,0.2>$ & $<0.8,0.2,0.1>$ & $<0.55,0.3,0.15>$ \\
\hline$A_{4}$ & $<0.7,0.25,0.2>$ & $<0.75,0.15,0.25>$ & $<0.85,0.2,0.05>$ & $<0.9,0.3,0.05>$ & $<0.9,0.15,0.25>$ \\
\hline
\end{tabular}

Source: Authors' calculations

Table 3. The ratings obtained based on the third expert

\begin{tabular}{|c|c|c|c|c|c|}
\hline & $C_{1}$ & $C_{2}$ & $C_{3}$ & $C_{4}$ & $C_{5}$ \\
\hline$w_{j}$ & 0.20 & 0.20 & 0.20 & 0.20 & 0.20 \\
\hline$A_{1}$ & $<0.6,0.2,0.35>$ & $<0.7,0.15,0.2>$ & $<0.6,0.2,0.2>$ & $<0.65,0.15,0.25>$ & $<0.4,0.3,0.35>$ \\
\hline$A_{2}$ & $<0.75,0.25,0.2>$ & $<0.75,0.2,0.25>$ & $<0.65,0.3,0.3>$ & $<0.55,0.2,0.3>$ & $<0.65,0.15,0.35>$ \\
\hline$A_{3}$ & $<0.7,0.15,0.2>$ & $<0.65,0.15,0.25>$ & $<0.55,0.4,0.35>$ & $<0.65,0.2,0.15>$ & $<0.65,0.2,0.15>$ \\
\hline$A_{4}$ & $<0.85,0.2,0.15>$ & $<0.7,0.15,0.15>$ & $<0.7,0.2,0.25>$ & $<0.75,0.2,0.25>$ & $<0.9,0.15,0.3>$ \\
\hline
\end{tabular}

Source: Authors' calculations 
The ranking orders obtained based on all the three experts are accounted for in Table 4.

Table 4. The ranking orders obtained from the three examinees

\begin{tabular}{|c|c|c|c|c|c|c|}
\hline & $E_{1}$ & $E_{2}$ & $E_{3}$ & $E_{1}$ & $E_{2}$ & $E_{3}$ \\
\hline & $S_{i}$ & $S_{i}$ & $S_{i}$ & Rank & Rank & Rank \\
\hline A1 & 0.910 & 0.900 & 0.880 & 2 & 4 & 4 \\
\hline A2 & 0.897 & 0.935 & 0.889 & 3 & 3 & 3 \\
\hline A3 & 0.821 & 0.942 & 0.910 & 4 & 2 & 2 \\
\hline A4 & 0.953 & 0.962 & 0.945 & 1 & 1 & 1 \\
\hline
\end{tabular}

Source: Authors' calculations

According to Table 4, the most appropriate alternative based on the theory of dominance is the alternative denoted as $A_{4}$.

The data in Table 4 indicate that the strategy designated as the A4 is best-ranked alternative. The strategy designated as A4 is based on the development of human resources in tourism.

In this paper we have proposed four strategies for the development of tourism in Eastern Serbia. The purpose of the strategy selection is to understand the key elements necessary for the development of tourism. The study shows four potential tourism development strategies and suggests an approach to select the best one in accordance with defined evaluation criteria. Based on the conducted research and analysis, the opinion of the expert in this field has led to the conclusion that the Strategy designated as A4 - human resources development in the tourism of eastern Serbia - is best ranked in terms of evaluation criteria.

In tourism, we can detect high level of personnel's interaction with consumers (tourists), therefore it is very important that people are well educated and trained in order to be able to provide the appropriate level of service quality (Urosevic, 2015; Cvijanovic and Vukovic, 2012). Tourism is one of the most important industries with rapid expansion and continuous growth, so it offers a large number of jobs (Thitthongkam and Walsh, 2010). In parallel with the development of tourism, there has been a development of professionals who linked their lives, work, economic and existential interests to tourism as a social and economic activity (Stefanović, 2009; Stefanović and Urošević, 2012). The personnel must be specially educated in order to establish direct contact with the guests and provide them with complete information (Vojnović et al., 2012). Personnel in tourism must have a broad general culture and education. Tourist business in most cases takes place through direct and on-the-spot contact between the tourist service providers and consumers/tourists. Therefore, the character of the personnel working in tourism is quite specific. In fact, personnel is directed to act on the principles of economic efficiency, but at the same time they must interact with their guests/tourists as selfless hosts, full of understanding for their needs (Vojnović et al., 2012). Apart from the traditional gastronomic skills, personnel in tourism are expected to be the creator of a new "healthy" diet. Tourists on vacation want direct contact with the gastronomy, so 
the host is expected to explain expertly, in the tourists' language, the ingredients and the procedure of meal preparation, so that after returning to their country they can prepare it by themselves.

Considering the increasing digitalization in tourism capacities, tourism personnel must have a significantly higher level of IT literacy, because the users of tourist services are nowadays people with high IT skills.

\section{Conclusion}

In the following years, it is necessary to work primarily on the image of Eastern Serbia as a tourist destination. This is an assumption, based on which we could carry out the positioning of this area in potential markets, which would capture the attention of potential segments of tourist consumers. In this paper, we have suggested four strategies for the development of tourism, where, on the basis of the relevant literature and the facts obtained on the field we have ranked them. Based on the conducted research, the opinions of competent experts in this field and the application of neutrosophic sets, it has been concluded that Strategy A4, based on the development of human resources in tourism, is the one that would be useful for the development of tourism in Eastern Serbia, because in almost all segments there is a lack in quality and educated personnel. All participants in the image creation and tourist products in the area of Eastern Serbia should be working in an organized manner. Local communities should create a favorable business environment and basic conditions for the development of this activity. Educational and research institutions should produce adequate personnel and provide interest-based connection and marketing performance in the function of raising the competitiveness of tourism products in this beautiful area.

\section{References}

1. Arsić, S., Nikolić, D., \& Živković, Ž. (2017). Hybrid SWOT-ANP-FANP model for prioritization strategies of sustainable development of ecotourism in National Park Djerdap, Serbia. Forest Policy and Economics, 80, 11-26.

2. Baušys, R., \& Juodagalvienė, B. (2017). Garage location selection for residential house by WASPAS-SVNS method. Journal of Civil Engineering and Management, 23(3), 421-429.

3. Čerović, S., \& Petović, P. (2006). Determining the priorities of tourism development in Serbia. Tourism, 10(6), 141-143. [in Serbian: Черовић, С., Петовић, П. (2006). Утврђивање приоритета развоја туризма Србије].

4. Cvijanović, D. (2014). Tourist market in the Danube Region. Institute of Agricultural Economics, Belgrade. [in Serbian: Цвијановић, Д. (2014). Туристичко тржиште у Дунавском региону].

5. Cvijanović, D., \& Vuković, P. (2012). The role of marketing in tourism in the Danube region of Serbia. Monograph, Institute of Agricultural Economics, Belgrade. [in Serbian: Цвијановић, Д., \& Вуковић, П. (2012). Улога маркетинга у туризму дунавског региона Србије]. 
6. Galanta, A., Anab, P., Slivarc, I., \& Pula, Z. (2016). Aligning wishes and environment sustainability: a focus on higher tourism consumption. Oktay Emira, Yalcin Arslanturkb, Savas Artugerc, 141.

7. Jawabreh, O. A. (2014). Tourism and the local community In Jordan and India. Pensee, 76(2).

8. Maksimović M., Urošević S., \& Karabašević D., (2016a). Mining heritage in the function of development of mining tourism on Stara Planina. 6 th International Symposium on natural resources management, 25-26 june, 2016. Zaječar. [in Serbian: Максимовић, М., Урошевић, С., \& Карабашевић, Д. (2016а). Рударско наслеђе у функцији развоја рударског туризма на Старој планини].

9. Maksimović, M., Urošević, S., \& Karabašević, D. (2016b). Strategy Positioning of Rural tourism on Stara Planina. HiT Management, Hotel Management and Tourism Management, 4(2), 112-121. [in Serbian: Максимовић, М., Урошевић, С., \& Карабашевић, Д. (2016б). Стратегија позиционирања руралног туризма Старе Планине].

10. Maksimović, M., Urošević, S., Stanujkić, D. \& Karabašević D. (2016c). Selection of a Strategy of the Development of Mining Tourism Based on a Grey Relational Analysis. Mining and Metallurgy Engineering Bor, 1, 115-124.

11. Nikolić, R., Urošević, S., Fedajev, A., \& Piljušić, M. (2013). Natural resource management as a function of environmental conservation. EMIT, Economics Management Information Technology, 2(1), 25-32.

12. Nurić, S., Nurić, A., Husić, M. \& Husić, H. (2015). Using the mining railway infrastructure for the tourism potential. QUAESTUS, multidisciplinary research journal, 6, 109-118.

13. Petrić, L., \& Mandić, A. (2014). Visitor management tools for protected areas focused on sustainable tourism development: the Croatian experience. Environmental Engineering and Management Journal, 13(6), 1483-1495.

14. Riznić, D., Voza, D., \& Vuković, M. (2011). Possibility of promoting specific forms of tourism in the border municipalities of northeastern Serbia. ThemesJournal of Social Sciences, 4, 1455-1473. [in Serbian: Ризнић, Д., Воза, Д., \& Вуковић, М. (2011). Могућности унапређења посебних облика туризма у пограничним општинама североисточне Србије].

15. Şahin, R.(2014).Multi-criterianeutrosophic decision making methodbased on scoreand accuracy functions under neutrosophic environment. arXiv preprint arXiv:1412.5202.

16. Smarandache, F. (1998). Neutrosophy: Neutrosophic Probability, Set, and Logic: Analytic Synthesis \& Synthetic Analysis.

17. Smarandache, F. (1999). Neutrosophy: A Unifying Field in Logics: Neutrosophic Logic. Neutrosophy, Neutrosophic Set, Neutrosophic Probability. American Research Press, Rehoboth. 
18. Stanujkic, D., Smarandache, F., Zavadskas, E. K., \& Karabasevic, D. (2016). Multiple Criteria Evaluation Model Based on the Single Valued Neutrosophic Set. Neutrosophic Sets \& Systems, 14.

19. Stefanović, V., \& Urošević, S. (2012). Human resources - a factor in the competitiveness of the tourism industry. Tourism: Challenges and Opportunities, Economic Institute, Belgrade, 20-22. September, 2012. Trebinje. [in Serbian: Стефановић, В., \& Урошевић, С. (2012). Људски ресурсифактор конкурентности туристичке привреде].

20. Stefanović, V. (2009). Human Resources Management in Tourism. PMF, Novi Sad. [in Serbian: Стефановић, В. (2009). Менаџмент људских ресурса у туризму].

21. Štetić, S. (2003). Strategy of development and placement of tourist destination. Tourism, 7(3),7-9. [in Serbian: Штетић, С. (2003). Стратегија развоја и пласмана туристичке дестинације].

22. Streimikiene, D., \& Bilan, Y. (2015). Review of Rural Tourism Development Theories. Transformations in Business \& Economics, 14(2), 21-34.

23. Thitthongkam, T., \& Walsh, J., (2010). Role of language in tourism organizational management. Asian Journal of Management Research, 1, 184-199.

24. Unković, S., \& Zečević, B. (2009). Economics of tourism. Faculty of Economics, Belgrade. [in Serbian: Унковић, С., \& Зечевић, Б. (2009). Економика туризма].

25. Urošević, S. (2015). Education and development of human resources in rural tourism. Applied Researches in Technics, Technologies and Education, ARTTE, 3(2), 143-149.

26. Urošević, S., Karabašević, D., \& Maksimović, M. (2015). The concept of sustainable development of rural tourism. XXIII International Conference Ecological Truth, Ecoist 15, 17-20 june 2015. Kopaonik, Serbia.

27. Vojnović, B., Cvijanović, D., \& Stefanović V. (2012). Developmental aspects of the tourist destination. Monograph, Institute of Agricultural Economics, Belgrade. [in Serbian: Војновић, Б., Цвијановић, Д., \& Стефановић, В. (2012). Развојни аспекти туристичке дестинације].

28. Wang, H., Smarandache, F., Zhang, Y., \& Sunderraman, R. (2010). Single valued neutrosophic sets. Review of the Air Force Academy, 1, 10.

29. Ye, J. (2014). A multicriteria decision-making method using aggregation operators for simplified neutrosophic sets. Journal of Intelligent \& Fuzzy Systems, 26(5), 2459-2466.

30. Zavadskas, E. K., Bausys, R., Kaklauskas, A., Ubarte, I., Kuzminske, A., \& Gudiene, N. (2017). Sustainable market valuation of buildings by the singlevalued neutrosophic MAMVA method. Applied Soft Computing, 57, 74-87. 